\title{
Burdah Keliling Ritual in the Role of Suistainable Security Management Case Study in Pesantren Salafiyah Syafiiyah Situbondo District, East Java, Indonesia
}

\author{
Atiqotul Fitriyah \\ University of Indonesia/faculty of humanities and social sciences
}

\begin{abstract}
Pesantren in Indonesia is renowned for a lot of rituals due to its belief with the sacred prayer. Burdah Keliling is known as a ritual for reading the qasidah Burdah Imam al Bushiri with a lot of songs by going around the pesantren at 00.00 am every day. One of those pesantren who had Burdah Keliling ritual is Salafiyah Syafiiyah. Burdah Keliling ritual as an oral tradition in pesantren Salafiyah Syafiiyah had been transmitted over four generations since 1900 M. Pesantren Salafiyah Syafiiyah had some belief and experience of the unseen attack and some supernatural disease. The Kiai as the head of pesantren decides to carry out the ritual to protect the pesantren from those attacks. The study sought to find out the role played by the rituals on the security management in Pesantren Salafiyah Syafiiyah. The study made use of a qualitative research method with ethnography approaches. 200 participants selected through the random sampling method were interviewed about the rituals as security management in Pesantren Salafiyah Syafiiyah. 10 of them are Kiai and Nyai, the head of pesantren as the main interview source, while others are the caretaker of pesantren and the santri who had directly involved in the ritual Burdah Keliling. This study finds out the Burdah Keliling ritual is a mandatory activity that has contributed to sustainable security management in the Pesantren. They believe and doing the Burdah Keliling ritual because of their belief in the mercy of Barokah and their obligation as santri in the pesantren.
\end{abstract}

Keyword: Ethnography; Oral Tradition; Pesantren; Ritual; Suistainble security Management. 